\title{
BIOMASS PRODUCTION OF ENERGY WILLOW UNDER UNFAVOURABLE FIELD CONDITIONS
}

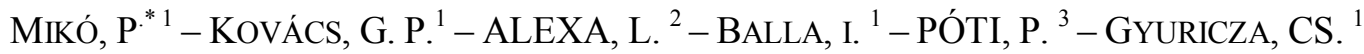 \\ ${ }^{I}$ Szent István University, Institute of Crop Production \\ ${ }^{2}$ Szent István University, Institute of Environmental Sciences \\ ${ }^{3}$ Szent István University, Institute of Animal Husbadry \\ H-2103 Gödöllö, Páter K. u. 1. \\ (phone: +36-28-522-000/1668; fax: +36-28-410-804) \\ *Corresponding author \\ e-mail:Miko.Peter@mkk.szie.hu \\ (Received $10^{\text {th }}$ September 2013; accepted $05^{\text {th }}$ December 2013)
}

\begin{abstract}
The production of woody energy crops may offer a real alternative for the utilisation of unfavourable cropping sites during the coming years. An experiment with woody energy crops on rustbrown forest soil was set up in 2007 at the Crop Production and Biomass Utilisation Demonstration Centre of Szent István University in the town of Gödöllő. The experiment was aimed at studying five willow varieties (Tora, Tordis, Inger, Sven, Csala) at three different nutrient levels (control, fertilisers, compost). We were seeking for the nutrient treatment and the variety that would produce the best results in a two-year harvesting schedule.In 2009 the average $(50.8 \mathrm{t} / \mathrm{ha})$ of the plots where fertilisers were applied exceeded the control yield ( $38.6 \mathrm{t} / \mathrm{ha}$ ) by $31.6 \%$ which was even exceeded by the plots where compost was applied (40.6 t/ha) by $5.2 \%$. In 2011 the yields after the application of fertilisers $(51.0 \mathrm{t} / \mathrm{ha})$ and compost (49.2 t/ha) exceeded the control yield (37.5 t/ha) by $36.0 \%$ and $31.2 \%$, respectively. In 2009 a $22.9 \%$ while in 2011 a $49.7 \%$ difference was found between the average yields of the two different groups of varieties, respectively. The Tordis and Sven varieties fell short of, while Csala, Inger and Tora exceeded the 40 t/ha two-year biomass yield in both 2009 and 2010. In view of the impacts of the different growing seasons further studies will need to be carried out in order to be able to choose the variety that is best suited to the given site.
\end{abstract}

Key words: short rotation coppice, biomass, willow, fertilizer, compost

\section{Introduction}

Owing to the scarcity of primary energy sources some $70 \%$ of Hungary's energy consumption is supplied from imports.

Renewable energy sources covered a mere $8.1 \%$ of Hungary's total energy consumption in 2009 according to Eurostat data. The European Union has set itself a target of covering an average of $20 \%$ of the energy sources of the 27 member states from renewable energy sources by year 2020 (Eurostat, 2012). The European Environmental Agency estimated that by 2030 some $20-30 \%$ of the total agricultural area of the European Union may be used for the production of energy crops (EEA, 2006). Hungary has also set itself a similar target (National Action Plan, 2010) but according to Eurostat's projection not more than about 13 percent should be expected to be achieved by 2020 (Eurostat, 2012).

Hungary has great potentials in terms of renewable energy sources. Particularly, the use of biomass and the utilisation of geothermal energy may play an important role in a longer term. Biomass production is currently the dominant form of Hungary's 
utilisation of renewable energy sources, as over $90 \%$ of the country's energy production from renewable sources originates from some form of biomass source (Szajkó, 2009; National Action Plan, 2010). During the forthcoming years this ratio will decrease but biomass will continue to be the most important renewable energy source in Hungary. The share of hydro and wind power in Hungary's energy economy is not likely to materially increase in the near future (Varga and Homonnai, 2009).

Three categories of biomass harvested from arable land for energy generation are distinguished: by-products of cropping, herbaceous and woody energy plants.

The utilisation of by-products of cropping for energy generation is limited by the growing shortage of organic matter in arable fields, as it is far more important to incorporate such materials in the soil either directly, or indirectly after utilisation as litter in livestock production in the form of farmyard manure, to maintain the quality and state of arable soils (Birkás et al., 2009).

Sites not suitable for economically efficient production of feeds or crops for human consumption are the areas that can be primary used for the production of herbaceous and woody energy crops. Decentralised power plants, relying on input materials that can be economically produced locally, may offer the best potentials for Hungary (Gyuricza, 2008). Such facilities may also have an important effect in the way of rural development, contributing to the restructuring of cropping in Hungary and to the creation of new jobs (Jolánkai, 2009).

The energy that can be produced on a unit area by growing energy crops is many times over the energy produced by growing cereals (Aylott et al., 2008).

Thanks to its continental climate Hungary has favourable conditions for the production of woody plant species such as for example acacia (Robinia sp.), willow (Salix sp.) and poplar (Populus sp.) (Tobisch et al., 2003; Ivelics, 2006; Barkóczy et al., 2007). These wood species are a source of a considerable amount of energy, e.g. about $19-20 \mathrm{MJ} / \mathrm{kg}$ energy can be generated from the soft-wood willow species after the wood has dried out (Demo et al., 2011; Mcelroy and Dawson, 1986; Mészáros et al., 2007).

Another argument in favour of the establishment of plantations is that apart from an occasional willow rust infection (Dawson and McCracken, 1995; McCracken and Dawson, 1998; PEI et al., 1993) and damage caused by willow leaf beetles (Ahman, and Lövgren, 1995; Larsson, 1998; Peacock et al., 1999; Sylvén and Lövgren, 1995) they do not tend to be attached by pathogens or pests, and in the majority of cases no crop protection activities are required in such plantations. Moreover, these plantations absorb considerable amounts of carbon-dioxide (Lemus and Lal, 2005; Galbraith et al., 2006; Sims et al., 2006).

The sizes and the total output of such of energy wood plantations in Hungary are way below the desirable: according to records kept by the National Food Chain Safety Office (NÉBIH) as many as 430 plantations had been established by end-2012 on a total area of 2169 hectares, with a 5.0 hectare available plantation size (NÉBIH, oral information).

Research on energy wood plantations has been varied in Hungary during the recent decades. Methods and technological variants that could be most securely and reliably applied in sites of different ecological conditions were worked out (Bai et al., 2008; Liebhard, 2009). Research has been focused on the choice of species and variety, the establishment of the optimum plant density, continued development of various vegetative propagation techniques, improvement of the planting technologies crop treatment and protection, methods and effects of crop nutrition and the storage, drying 
and other forms of utilisation of the harvested wood material (Ivelics, 2006; Barkóczy et al., 2007; Gyuricza et al., 2011).

The increasing frequency of weather extremes however, necessitates further studies to ensure optimum nutrient supplies for energy wood plantations established in unfavourable growing sites. Our study was aimed at showing the biomass outputs of an energy willow experiment on brown forest soil near the town of Gödöllö, in the case of different nutrient treatments.

\section{Material and methods}

Our woody energy plantation experiment was set up in 2007 at the Crop Production and Biomass Utilisation Demonstration Centre of Szent István University in the town of Gödöllö. According to the genetic soil classification system applied in Hungary the soil of the site of the experiment is a rust-brown forest soil on a sandy basis for the most part (Luvic Calcic Phaeozem). The rust-brown forest soil sub-type developed on tertiary sand and marl belongs to the 'Rannan' brown forest soil type. The processes of soil degradation have created a variety of a medium-depth fertile layer of low humus content.

The area is exposed to erosion, the soil's physical type is sand-loam, which is prone to settle. The top $20 \mathrm{~cm}$ layer is comprised of 53\% sand, $26 \%$ loam and $20 \%$ clay. The $35 \mathrm{~cm}$ topsoil layer contains $26 \%$ clay, it has favourable water conductivity, in contrast to the poor water conductivity of the subsoil layer. The topsoil has a low humus and nitrogen content, but it is adequately supplied with potassium and phosphorous. Some of the key data of the soil of the experimental plot are summarised in Table 1.

Table 1. Major pedological data

\begin{tabular}{|c|c|c|c|c|c|c|c|c|c|}
\hline & Genetic soil & pH & & humus & $\mathrm{CaCO}_{3}$ & Total salt & Total nitrogen & $\mathbf{A L}-\mathbf{P}_{2} \mathrm{O}_{5}$ & $\mathbf{A L}-\mathbf{K}_{2} \mathbf{O}$ \\
\hline & horizon & $\left(\mathbf{H}_{2} \mathrm{O}\right)$ & $\mathbf{K}_{\mathbf{A}}$ & & $\%$ & & & $\mathrm{~g} \cdot \mathrm{kg}^{-1}$ & \\
\hline A & $(0-40 \mathrm{~cm})$ & 6.76 & 30 & 1.32 & 0.00 & 0.044 & 16.8 & 371.1 & 184.0 \\
\hline B & $(40-60 \mathrm{~cm})$ & 7.08 & 40 & 1.04 & 0.00 & 0.052 & 11.9 & 33.0 & 112.0 \\
\hline $\mathrm{BC}$ & $(60-70 \mathrm{~cm})$ & 7.66 & 61 & 0.88 & 0.00 & 0.060 & 2.0 & 123.0 & 127.1 \\
\hline $\mathrm{C}$ & $(70-100 \mathrm{~cm})$ & 8.10 & 60 & 0.54 & 5.57 & 0.075 & 16.8 & 107.5 & 110.8 \\
\hline
\end{tabular}

The climate in the area of the experiment is continental, with frequent weather extremes. The multi-year average temperature is $9.7{ }^{\circ} \mathrm{C}$. The average annual precipitation is $550 \mathrm{~mm}$, two thirds of which falls in the form of rain during the growing season. Data of the weather during the years of our experiment (2007-2011) are presented in Table 2.

The experiment was of a two-factor type, in random block arrangement, in three iterations. The following five different willow variants and clones:

1. Csala (Salix triandra $\mathrm{x}$ Salix viminalis 'Csala')

2. Tora (Salix schwerinii x Salix viminalis 'Tora')

3. Tordis (Salix schwerinii x Salix viminalis 'Tordis')

4. Inger (Salix triandra x Salix viminalis 'Inger')

5. Sven (Salix schwerinii x Salix viminalis 'Sven') 
were used in the experiment, with three different nutrient supply levels in each case: 1 surface cover with compost (50 t/ha); 2 - nitrogen fertiliser in the spring $(50 \mathrm{~kg} / \mathrm{ha})$; and 3 - control without added nutrients. The compost and the fertiliser were both applied in early May, in the pairs of rows. The applied technology was one of a twin-row type, with $70 \mathrm{~cm}$ distances between the rows and 2.5 metres between the twin-rows. The space between the plants was $40 \mathrm{~cm}$ in the case of four variants (Tora, Inger, Sven and Tordis), while in the case of Csala, a variant of less vigorous growth, it was $30 \mathrm{~cm} .25$ $\mathrm{cm}$ cuts without roots were used for planting the trees, manually, in mid-April. Chemical weed control - with pendimethaline as active agent - took place in the year of planting in the twin-rows. This was supplemented by mechanical weed control using a rotary cultivator twice between the twin-rows. From year 2008 on, the spaces between the twin-rows were tilled with the rotary cultivator twice a year. There was no need for chemical control of pests and pathogens.

Table 2. Meteorological data of years of experiment (Gödöllö, 2007-2011)

\begin{tabular}{|c|c|c|c|c|c|c|c|c|}
\hline \multicolumn{9}{|c|}{ (Rainfall (mm) } \\
\hline Years & April & May & June & July & August & September & $\begin{array}{c}\text { Total } \\
\text { (April - } \\
\text { September) }\end{array}$ & $\begin{array}{l}\text { Annual } \\
\text { rainfall }\end{array}$ \\
\hline 2007 & 5.8 & 44.0 & 63.2 & 21.8 & 69.0 & 46.0 & 249.8 & 518.2 \\
\hline 2008 & 34.4 & 59.6 & 66.8 & 200.8 & 28.6 & 82.0 & 472.2 & 688.2 \\
\hline 2009 & 2.0 & 28.0 & 54.0 & 18.0 & 27.0 & 4.0 & 133.0 & 392.2 \\
\hline 2010 & 40.4 & 161.4 & 172.0 & 43.0 & 38.0 & 106.6 & 561.4 & 757.4 \\
\hline 2011 & 4.6 & 25.2 & 45.8 & 59.0 & 4.6 & 1.0 & 140.2 & 272.8 \\
\hline \multicolumn{9}{|c|}{ Temperature $\left({ }^{\circ} \mathrm{C}\right)$} \\
\hline Years & April & May & June & July & August & September & $\begin{array}{c}\text { Average } \\
\text { (April - } \\
\text { September) }\end{array}$ & $\begin{array}{l}\text { Annual } \\
\text { average }\end{array}$ \\
\hline 2007 & 13.7 & 18.6 & 22.6 & 24.1 & 22.9 & 14.1 & 19.3 & 12.1 \\
\hline 2008 & 11.9 & 17.5 & 21.6 & 21.6 & 21.9 & 15.5 & 18.3 & 11.7 \\
\hline 2009 & 15.4 & 17.6 & 18.2 & 22.6 & 21.8 & 18.3 & 19.0 & 11.2 \\
\hline 2010 & 11.1 & 15.2 & 20.2 & 22.3 & 20.3 & 13.4 & 17.1 & 9.7 \\
\hline 2011 & 11.6 & 16.4 & 19.9 & 19.9 & 21.2 & 19.0 & 18.0 & 10.8 \\
\hline
\end{tabular}

The plantation was cut on 26 February 2008, after the year of planting, to encourage bud production. The complete two-year's growth was then harvested on 18 February 2010 and on 12 January 2012, when we also measured the quantity of the biomass. The dry mass and the moisture content was established after desiccating until reaching a constant mass at $105^{\circ} \mathrm{C}$.

Statistical evaluation was carried out with the help of the SPSS.

\section{Results and discussion}

In the case of the two-year growth in 2009 the largest amount of biomass was harvested from the plot where fertiliser had been applied (Table 3). The two-year growth produced a $50.8 \mathrm{t} /$ ha wet mass. The yield on the plot where fertiliser had been applied differed significantly $\left(\mathrm{SD}_{5 \%}=4.4\right)$ from the biomass produced on the plot with compost and the control plot. There was no difference at a 5\% significance level 
between the compost-covered plot and the control area: the former produced a yield $5.1 \%$ more than the latter. The modest yield-increasing effect of the $50 \mathrm{t} / \mathrm{ha}$ compost was explained by the fact that as little as $392.2 \mathrm{~mm}$ precipitation was recorded in the experimental area in $2009-133.0 \mathrm{~mm}$ of which fell in the form of rain during the period of April to September, the most important period for the growth of willow - so the nutrients contained in the compost could not decompose and pass down to the root zone. In a rainy year the retarded nutrient supply from the decomposing of compost may even be an advantage, since in this case hardly any of the nitrogen is bleached out of the soil (Adegbidi and Briggs, 2003).

The average biomass yield of the plots treated with fertiliser exceeded the control and the compost-covered plots by $31.6 \%$ and $25.1 \%$, respectively. The easily dissolved fertiliser reached the root zone despite the shortage of soil moisture, where it could be taken up by the plants, increasing their growth. Moreover, by improving the water uptake of the plants the nutrient so utilised alleviated the symptoms caused by the drought. This is all the more important because the most intensive period of growth and water uptake often coincides in the case of willow species with the driest periods of the year (Hall and Allen, 1997; Lindroth and Bath, 1999).

Under unfavourable site conditions the yield of the energy wood plantation harvested every other year reached in 2009, even in the control plots, the levels measured in some international experiments (Cannel et al., 1987; Mcelroy and Dawson, 1993; Kowalik and Randerson, 1994; Labercque et al., 1997; Aylott et al., 2008,) and exceeded those measured in other studies (Bullard et al., 2002a; Bullard et al., 2002b).

Table 3. Analysis of variance of biomass according to nutrient level in 2009

\begin{tabular}{|l|r|r|r|r|r|}
\hline & \multicolumn{1}{|c|}{$\begin{array}{c}\text { Sum of } \\
\text { Squares }\end{array}$} & $\begin{array}{c}\text { Degree of } \\
\text { freedom }\end{array}$ & $\begin{array}{c}\text { Mean } \\
\text { Square }\end{array}$ & F value & \multicolumn{1}{c|}{$\begin{array}{c}\text { Calculated } \\
\text { significance }\end{array}$} \\
\hline Between groups & 1166.760 & 2 & 583.380 & 14.033 & 0.000 \\
Within groups & 1746.041 & 42 & 41.572 & & \\
Total & 2912.801 & 44 & & & \\
\hline
\end{tabular}

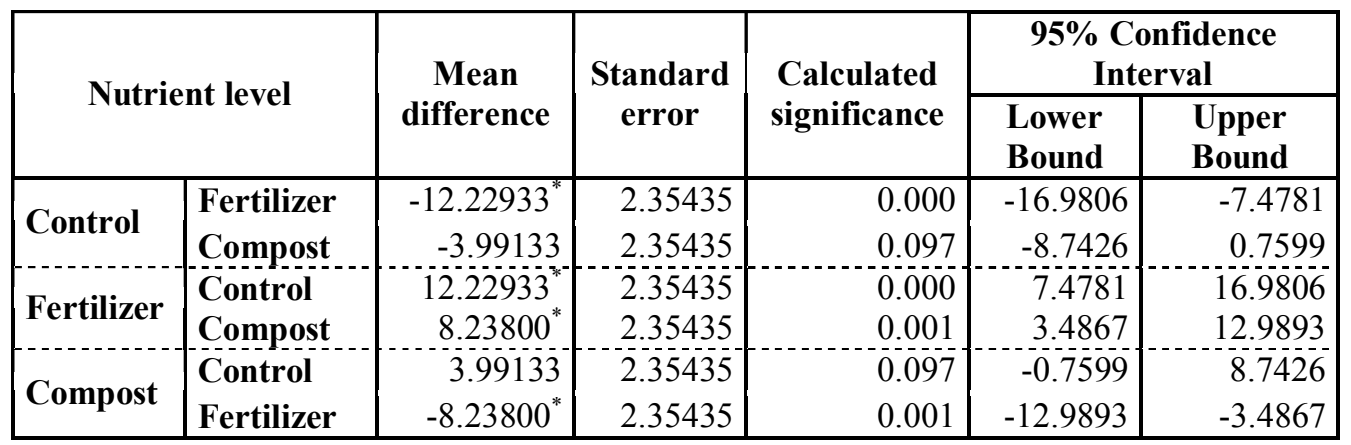

* significance level 0.05

In the case of the two-year growth harvested in 2009 the largest biomass was produced by the Inger variety (48.2 t/ha), at a 5 percent confidence level its biomass yield significantly $\left(\mathrm{SD}_{5 \%}=3.9\right)$ exceeded the yield of the Tordis $(39.6 \mathrm{t} / \mathrm{ha})$ and the Sven (39.2 t/ha) varieties (by $21.7 \%$ and $22.9 \%$, respectively) (Table 4 ). Its biomass yield did not, however, statistically exceed that of the Csala $(43.2 \mathrm{t} / \mathrm{ha})$ and the Tora $(46.4 \mathrm{t} / \mathrm{ha})$ varieties at a $5 \%$ confidence level. No significant differences were found in the biomass yields of the other varieties. One reason for this is that the Tora, the Tordis and the Sven 
varieties have a largely common genetic background (Stackeviciene et al., 2010; Jereková et al., 2011).

Though Labecque and Teodorescu (2005) harvested a larger amount of growth in Canada a one-year harvest cycle calculated for a two-year period, however, the average annual precipitation there is $952 \mathrm{~mm}$, i.e. they had more rain during the growing season only, than in Hungary during the whole of year 2009.

Table 4. Analysis of variance of biomass according to varieties in 2009

\begin{tabular}{|l|r|r|r|r|r|}
\hline & \multicolumn{1}{|c|}{$\begin{array}{c}\text { Sum of } \\
\text { Squares }\end{array}$} & $\begin{array}{c}\text { Degree of } \\
\text { freedom }\end{array}$ & $\begin{array}{c}\text { Mean } \\
\text { Square }\end{array}$ & F value & $\begin{array}{c}\text { Calculated } \\
\text { significance }\end{array}$ \\
\hline Between groups & 573.422 & 4 & 143.356 & 2.136 & 0.094 \\
Within groups & 2684.672 & 40 & 67.117 & & \\
Total & 3258.094 & 44 & & & \\
\hline
\end{tabular}

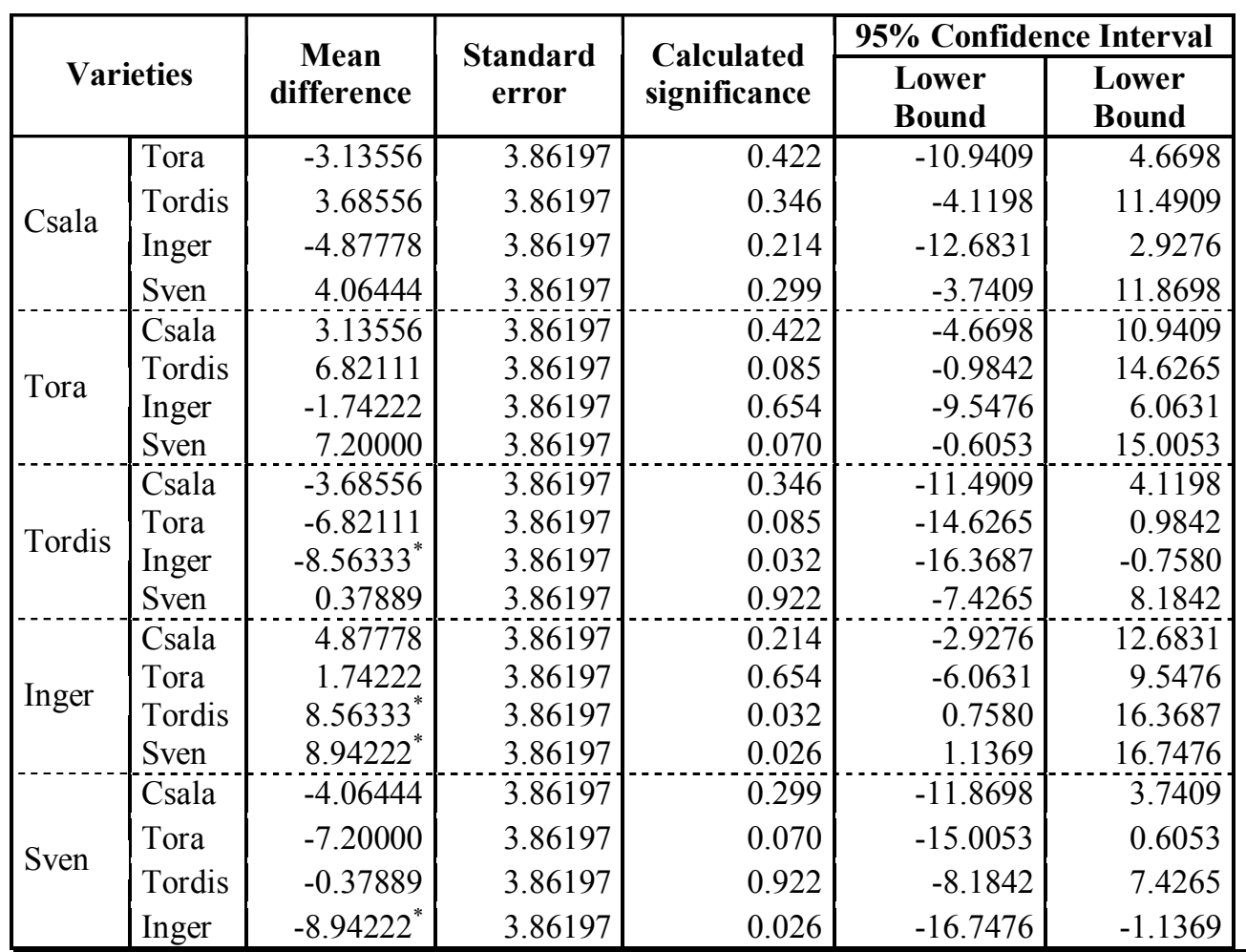

* significance level 0.05

Similarly to the preceding harvest cycle in the case of the two-year growth cut in 2011 the largest biomass was produced in the fertilised plot $(51.0 \mathrm{t} / \mathrm{ha}), 36.0 \%$ more than in the control plot $(37.5 \mathrm{t} / \mathrm{ha})$. There was no statistically confirmed difference $\left(\mathrm{SD}_{5 \%}=3,5\right)$ between the average of the fertilised and that of the compost-covered plot $(49.2 \mathrm{t} / \mathrm{ha})$, in that two-year period the plot with the fertiliser applied produced only $3.6 \%$ more biomass that did the control. Compost produced $31.2 \%$ more biomass than the control plot (Table 5).

The $21.2 \%$ yield increase in 2011 in the plot with the compost in comparison to 2009 must have been enabled by the fact that the nutrients contained in the compost layer had decomposed and found their way to the root zone by that time. Under the unfavourable site conditions and in the soil that tends to settle the process took somewhat more time 
(Epsein et al., 1976; Aggelides and Londra, 2000), though it was accelerated by the higher than average precipitation $(757.4 \mathrm{~mm})$ in 2010 . Although year 2011 was a very dry year (272.8 $\mathrm{mm}$ precipitation), with only $140.2 \mathrm{~mm}$ rainfall during the growing season, the required moisture content was available from the preceding year's surplus.

A $0.4 \%$ yield increase was recorded in the fertilised plot in comparison to 2009 . Since no nutrient had been applied in the control plot during the whole of the experiment, the biomass harvested in 2011 was 2.8 percent below the yield in 2009 .

Table 5. Analysis of variance of biomass according to nutrient level in 2011

\begin{tabular}{|l|r|r|r|r|r|}
\hline & \multicolumn{1}{|c|}{$\begin{array}{c}\text { Sum of } \\
\text { Squares }\end{array}$} & $\begin{array}{c}\text { Degree of } \\
\text { freedom }\end{array}$ & $\begin{array}{c}\text { Mean } \\
\text { Square }\end{array}$ & F value & $\begin{array}{c}\text { Calculated } \\
\text { significance }\end{array}$ \\
\hline Between groups & 2505.439 & 2 & 1252.720 & 23.642 & 0.000 \\
Within groups & 2225.409 & 42 & 52.986 & & \\
Total & 4730.848 & 44 & & & \\
\hline
\end{tabular}

\begin{tabular}{|l|l|r|r|r|r|r|}
\hline \multicolumn{2}{|c|}{ Nutrient level } & \multirow{2}{*}{$\begin{array}{c}\text { Mean } \\
\text { difference }\end{array}$} & $\begin{array}{c}\text { Standard } \\
\text { error }\end{array}$ & $\begin{array}{c}\text { Calculated } \\
\text { significance }\end{array}$ & \multicolumn{2}{c|}{$\begin{array}{c}\text { 95\% Confidence } \\
\text { Interval }\end{array}$} \\
\cline { 5 - 7 } & & & $\begin{array}{c}\text { Lower } \\
\text { Bound }\end{array}$ & \multicolumn{1}{c|}{$\begin{array}{c}\text { Lower } \\
\text { Bound }\end{array}$} \\
\hline Control & Fertilizer & $-15.78547^{*}$ & 2.65797 & 0.000 & -21.1495 & -10.4215 \\
\hdashline & Compost & $-15.87134^{*}$ & 2.65797 & 0.000 & -21.2353 & -10.5073 \\
\hline Fertilizer & Control & $15.78547^{*}$ & 2.65797 & 0.000 & 10.4215 & 21.1495 \\
\hline Compost & Compost & -0.08587 & 2.65797 & 0.974 & -5.4499 & 5.2781 \\
& Control & $15.87134^{*}$ & 2.65797 & 0.000 & 10.5073 & 21.2353 \\
& Fertilizer & 0.08587 & 2.65797 & 0.974 & -5.2781 & 5.4499 \\
\hline
\end{tabular}

* significance level 0.05

The year 2011 yield was highest among the varieties in the case of the one called Csala (53.6 t/ha), significantly higher than those of Tordis (39.6 t/ha) and Sven $(39.2$ $\mathrm{t} / \mathrm{ha})\left(\mathrm{SD}_{5 \%}=4.3\right)$ (Table 6$)$. Tora's yield was $46.4 \mathrm{t} / \mathrm{ha}$. The best variety (Csala) yielded $49.7 \%$ more than the least well performing variety (Tordis). The substantial difference was caused by the fact that the high performing Swedish varieties are characterised by poor drought tolerance (Lindroth and Bath, 1999; Wikberg and Ogren, 2004; Cochard et al., 2007).

Inger, which produced the largest biomass in 2009 yielded a $51.5 \mathrm{t} / \mathrm{ha}$ two-year growth in 2011. Though its yield was $4.0 \%$ below that of Csala, the difference between Inger and the other varieties could not be statistically proven at a 5\% confidence level. Both varieties comprise the Salix triandra parental line (Stackeviciene et al., 2010; Jereková et al., 2011) which must have provided the higher resistance and biomass, but owing to Csala's slower initial growth could not appear in 2009 but was already manifested in 2011.

Csala's yield increased by $204.0 \%$ by 2011 in comparison to 2009 . The yield increase was $6.8 \%$ in the case of Inger and $6.0 \%$ in the case of Tora. The Sven variety's biomass output increased by only $0.3 \%$, while that of Tordis dropped by $9.5 \%$. The reason for this may lie in the fact that for the clones produced in Sweden on the basis of the Salix schwerinii parental line it takes a shorter period of time to deliver their maximum biomass yield. As a consequence of the loss of foliage caused by unfavourable environmental conditions even the self-shading of the vigorously growing stand may result in a loss of yield (Bullard et al., 2002b).

Table 6. Analysis of variance of biomass according to varieties in 2011 


\begin{tabular}{|l|r|r|r|r|r|}
\hline & \multicolumn{1}{|c|}{$\begin{array}{c}\text { Sum of } \\
\text { Squares }\end{array}$} & $\begin{array}{c}\text { Degree of } \\
\text { freedom }\end{array}$ & \multicolumn{1}{c|}{$\begin{array}{c}\text { Mean } \\
\text { Square }\end{array}$} & F value & \multicolumn{1}{c|}{$\begin{array}{c}\text { Calculated } \\
\text { significance }\end{array}$} \\
\hline Between & 2242.830 & 4 & 560.707 & 6.930 & 0.000 \\
groups & 3236.381 & 40 & 80.910 & & \\
Within groups & 5479.211 & 44 & & & \\
Total & & & \\
\hline
\end{tabular}

\begin{tabular}{|c|c|c|c|c|c|c|}
\hline & & & & & 95\% Confide & e Interval \\
\hline Var & eties & $\begin{array}{l}\text { Mean } \\
\text { difference }\end{array}$ & $\begin{array}{l}\text { Standard } \\
\text { error }\end{array}$ & $\begin{array}{l}\text { Calculated } \\
\text { sionificance }\end{array}$ & Lower & Lower \\
\hline & Tora & 4.39470 & 4.62909 & 0.348 & -4.9610 & 13.7504 \\
\hline Coolo & Tordis & $10.37654^{*}$ & 4.62909 & 0.031 & 1.0208 & 19.7323 \\
\hline Csala & Inger & 2.09553 & 4.62909 & 0.653 & -7.2602 & 11.4513 \\
\hline & Sven & $11.00125^{*}$ & 4.62909 & 0.022 & 1.6455 & 20.3570 \\
\hline & Csala & -4.39470 & 4.62909 & 0.348 & -13.7504 & 4.9610 \\
\hline Tora & Tordis & 5.98184 & 4.62909 & 0.204 & -3.3739 & 15.3376 \\
\hline Tora & Inger & -2.29917 & 4.62909 & 0.622 & -11.6549 & 7.0566 \\
\hline & Sven & 6.60655 & 4.62909 & 0.161 & -2.7492 & 15.9623 \\
\hline & Csala & $-10.37654^{*}$ & 4.62909 & 0.031 & -19.7323 & -1.0208 \\
\hline Tordic & Tora & -5.98184 & 4.62909 & 0.204 & -15.3376 & 3.3739 \\
\hline Tordis & Inger & -8.28102 & 4.62909 & 0.081 & -17.6368 & 1.0747 \\
\hline & Sven & 0.62471 & 4.62909 & 0.893 & -8.7310 & 9.9805 \\
\hline & Csala & -2.09553 & 4.62909 & 0.653 & -11.4513 & 7.2602 \\
\hline & Tora & 2.29917 & 4.62909 & 0.622 & -7.0566 & 11.6549 \\
\hline Inger & Tordis & 8.28102 & 4.62909 & 0.081 & -1.0747 & 17.6368 \\
\hline & Sven & 8.90572 & 4.62909 & 0.062 & -0.4500 & 18.2615 \\
\hline & Csala & $-11.00125^{*-}$ & 4.62909 & 0.022 & -20.3570 & -1.6455 \\
\hline Syon & Tora & -6.60655 & 4.62909 & 0.161 & -15.9623 & 2.7492 \\
\hline Sven & Tordis & -0.62471 & 4.62909 & 0.893 & -9.9805 & 8.7310 \\
\hline & Inger & -8.90572 & 4.62909 & 0.062 & -18.2615 & 0.4500 \\
\hline
\end{tabular}

\section{Conclusions}

The majority of unfavourable sites that cannot be economically used for the production of other crops are suitable for energy wood plantations in Hungary. This is a costly investment therefore it is key that the species and variety that is the most productive under the given conditions should be planted at the different sites. Though there is ample and detailed literature on the theme, there is a relative shortage of experimental results produced specifically in circumstances prevailing in Hungary.

Our experiments show that willow plantations under the unfavourable site conditions of the Gödöllö region can produce the amounts of biomass described in reports on foreign experiments even in extremely dry years. The Swedish varieties used in our experiment (Tora, Tordis, Inger and Sven) produced the yields observed in their own genetic centres even in the Carpathian basin.

An amount of $50 \mathrm{~kg} / \mathrm{ha}$ nitrogen fertiliser was enough in both years to significantly increase the biomass growth. It is recommended to be delivered to the fields concerned in the spring after harvest.

The yield increasing effect of compost was not observed to a statistically confirmed degree before 2011. The reason for this was that its nutrient content took longer to reach the root zone but in view of its soil protecting effects its use is always recommended right from the time of plantation. 
In both of the two-year growing cycles (2008-2009 and 2010-2011) there was one dry and one rainy year, therefore in view of the year effects there is a need for further studies to make it possible to choose the willow variety best suited to a given site.

Acknowledgements. Research was supported by the TÁMOP-4.2.A-11/1/KONV, Research Centre of Excellence- 8526-5/2014/TUDPOL.

\section{REFERENCES}

[1] Adegbidi H. G., Briggs, R. D. (2003): Nitrogen mineralization of sewage sludge and composted poultry manure applied to willow in a greenhouse experiment. - Biomass and Bioenergy 25(6): 665-673.

[2] Aggelides, S. M., Londra, P. A. (2000): Effects of compost produced from town wastes and sewage sludge on the physical properties of a loamy and a clay soil. - Bioresource Bioresource Technology 71(3): 253-259.

[3] Ahman, I., Lövgren, L. (1995): Host relationships of Dasineura ingeris: oviposition preferences and juvenile survival on clones of Salix viminalis, other Salix species and hybrids. - Entomologia Experimentalis et Applicata 77: 23-30.

[4] Aylott, M. J. Casella, E., Tubby, I., Street, N. R., Smith, P., Taylor, G. (2008): Yield and spatial supply of bioenergy poplar and willow short-rotation coppice in the UK. - New Phytologist 178: 358-370.

[5] Bai A., Lackner, Z., Marosvölgyi, B., Nábrádi, A. (2008): A biomassza felhasználása. (Biomass utilisation) Szaktudás Kiadó. Budapest.

[6] Barkóczy, Zs., Csernyi, R., Ivelics, R. (2007): Energetikai faültetvények tervezése és kivitelezése. (Designing and implementing energy wood plantations) Kézirat. (Manuscript) Sopron.

[7] Birkás M., Stingli, A., Farkas, Cs., Bottlik, L. (2009): Összefüggés a művelés eredetű tömörödés és a klímakárok között. (Relationship between tillage-induced compaction and climate damage) - Növénytermelés 58(3): 5-26.

[8] Bullard, M. J. Mustill, S. J., Carver, P., Nixon, P. M. I. (2002b): Yield improvements through modi_cation of planting density and harvest frequency in short rotation coppice Salix spp. -2 . Resource capture and use in two morphologically diverse varieties. - Biomass and Bioenergy 22: 27-39.

[9] Bullard, M. J., Mustill, S. J., McMillan, S. D., Nixon, P. M. I., Carver, P., Britt, C. P. (2002a): Yield improvements through modi_cation of planting density and harvest frequency in short rotation coppice Salix spp. - 1. Yield response in two morphologically diverse varieties. - Biomass and Bioenergy 22: 15-25.

[10] Cannell, M. G. R. Milne, R., Sheppard, L. J., Unsworth, M. H. (1987): Radiation interceptionand productivity of willow. - Journal of Applied Ecology 24: 261-278.

[11] Cochard, H., Casella, E., Mencuccini, M. (2007): Xylem vulnerability to cavitation varies among poplar and willow clones and correlates with yield. - Tree Physiology 27: 17611767.

[12] Dawson, W. M., McCracken, A. R. (1995): The performance of polyclonal stands in short rotation coppicewillow for energy production. - Biomass and Bioenergy 8(1): 1-5.

[13] Demo, M. Fazekas, A., Hauptvogl, M., Skladan, B., Tóthová, M. (2011): Produkčný a anergetický potenciál švédskych odrôd rýchlorastúcej enrgetickej dreviny rodu Salix pestovanej v suchších pôdno-klimatických podmienkach juhozápadného Slovenska. SPU Nitra. 110.

[14] EEA. (2006): How much bioenergy can Europe produce without harming the environment? Copenhagen, Denmark: European Environment Agency. 
[15] Epsein, E., Taylor, T. M., Chancy, R. L. (1976): Effects of Sewage Sludge and Sludge Compost Applied to Soil on some Soil Physical and Chemical Properties. - Journal of Environmental Quality 5(4): 422-426.

[16] Eurostat. (2012): Renewable energy. The contribution of renewable energy up to $2.4 \%$ of energy consumption in the EU27 in 2010. http://europa.eu/rapid/pressReleasesAction.do?reference=STAT/12/94andformat=HTML andaged $=0$ andlanguage $=$ ENandguiLanguage $=$ en Downloads: 2012.08.30.

[17] Galbraith, D., Smith, P., Mortimer, N., Stewart, B., Hobson, M., McPherson, G., Matthews, R., Mitchell, R., Nijnik, M., Norris, J. (2006): Review of greenhouse gas life cycle emissions, air pollution impacts and economics of biomass production and consumption in Scotland. SEERAD Project Final Report FF/05/08. Edinburgh, UK: Scottish Executive.

[18] Gyuricza C. (2008): Cukorcirok termesztése energetikai hasznosításra. (Production of sugar sorghum as an energy crop) Agronapló 12. 4: 75-76.

[19] Gyuricza Cs., Hegyesi, J., Kolhelb, N. (2011): Rövid vágásfordulójú füz (Salix sp.) energiaültetvény termesztésének tapasztalatai és életciklus-elemzésének eredményei. (Experience drawn from the production of short harvest cycle willow (Salix sp.) as energy crop and results of its life cycle analysis) - Növénytermelés 60(2): 45-65.

[20] Hall, R. L., Allen, S. J. (1997): Water use of poplar clones grown as short-rotation coppice at two sites in the United Kingdom. -. Aspects of Applied Biology 49: 163-172.

[21] Ivelics R. (2006): Minirotációs energetikai faültetvények termesztés-technológiájának és hasznosításának fejlesztése. (Development of the production technology and the utilisation of mini-rotation energy food plantations) Kézirat. (Manuscript) Sopron.

[22] Jereková, Z. Drazic, G., Kotrla, M., Marisová, E., Milovanovic, J., Tóthová, M., Konceková (2011): Biological factors influencing The growth and biomass production of willows planted in Southern Slovakia. - Acta Regionalia et Environmentalica 2: 47-52.

[23] Jolánkai M. (2009): Energetikai növénytermesztés környzet- és talajvédelmi aspektusai, MTA SZIE Agronómiai Kutatócsoport. (Environmental and soil protection aspects of energy crop production, HAS SZIE Agronomy Research Team) AKAPRINT Kiadó. Budapest

[24] Kowalik, P. J., Randersonc, P. F. (1994): Nitrogen and phosphorus removal by willow stands irrigated with municipal waste water - a review of the polish experience. Biomass Bioenergy 6:133-139.

[25] Labrecque, M. Teodorescu, T. I., Daigle, S. (1997): Biomass productivity and wood energy of Salix species after 2 years growth in sric fertilized with wastewater sludge. Biomass and Bionergy 12(6): 409-417.

[26] Labrecque, M., Teodorescu, T. I. (2005): Field performance and biomass production of 12 willow and poplar clones in short-rotation coppice in southern Quebec (Canada). Biomass and Bioenergy 29: 1-9.

[27] Larsson, S. (1998): Genetic improvement of willow for short-rotation coppice. - Biomass and Bioenergy 15(1): 23-26.

[28] Lemus, R., Lal, R. (2005): Bioenergy crops and carbon sequestration. - Critical Reviews in Plant Sciences 24: 1-21.

[29] Liebhard P. (2009): Energetikai faültetvények. (Energy wood plantations) Cser Kiadó. Budapest.

[30] Lindroth, A., Bath, A. (1999): Assessment of regional willow coppice yield in Sweden on basis of water availability. - Forest Ecology and Management 121. 57-65.

[31] McCracken, A. R, Dawson, W. M. (1998): Short rotation coppice willow in Northern Ireland since 1973: development of the use of mixtures in the control of foliar rust (Melampsora spp.). - European Journal of Forest Pathology 28(4): 241-250.

[32] Mcelroy, G. H., Dawson, W. M. (1993): Biomass from short-rotation coppice willow on marginal land. - Biomass 10(3): 225-240. 
[33] Mészáros E. Jakab, E., Várhegyi, G., Tóvári, P. (2007): Thermogravimetry/Mass Spectrometry analysis of energy crops. - Journal of Thermal Analysis and Calorimetry. 88(2): 477-482.

[34] Nemzeti Cselekvési Terv. (2010): Magyarország Megújuló Energia Hasznosítási Cselekvési Terve 2010-2020. A 2020-ig terjedő megújuló energiahordozó felhasználás alakulásáról. (Hungary's renewable energy source utilisation action plan 2010-2020. On the development of the utilisation of renewable energy sources up to 2020)

[35] Peacock, L., Herrick, S., Brain, P. (1999): Spatio-temporal dynamics of willow beetle (Phratora vulgatissima) in short-rotation coppice willows grown as monocultures or a genetically diverse mixture. - Agricultural and Forest Entomology 1(4): 287-296.

[36] Pei, M. H., Royle, D. J., Hunter, T. (1993): Identity and host alternation of some willow rusts (Melampsora spp.) in England. Mycological Research. 97. 845-851.

[37] Sims, R. H., Hastings, A., Schlamadinger, B., Taylor, G., Smith, P. (2006): Energy crops: current status and future prospects. - Global Change Biology 12: 2054-2076.

[38] Stackeviciene, E., Matelis, A., Grigaliunatie, B. (2010): Cultivation of the introduced Salix plants in plantations. - Acta Biologica Universitatis Daugavpiliensis. 10(2): 173176.

[39] Sylvén, E., Lövgren, L. (1995): Dasineura ingeris sp. n. (Diptera: Cecidomyiidae) on Salix viminalis in Sweden, including comparisons with some other Dasineura species on Salix. - Systematic Entomology 20: 59-71.

[40] Szajkó, G. (2009): Erdészeti és ültetvény eredetű fás szárú biomassza Magyarországon. (Woody biomass from forest management and from plantations in Hungary) Regionális Energiagazdasági Kutatóközpont. (Regional Energy Economy Research Centre) Mühelytanulmány. (Workshop study) 99.

[41] Tobisch, T., Csontos, P., Rédei, T., Führer, E. (2003): Fehér akác (Robinia pseudoacacia L.) faállományok vizsgálata aljnövényzetük összetétele alapján. - Tájökológiai Lapok 1(2): 61-70.

[42] Varga, K., Homonnai, G. (2009): Munkahelyteremtés zöldenergiával - A megújuló energiaforrások munkahelyteremtő hatásának nemzetközi tapasztalatai. (Job creation with green energy - International experience of job creating effects associated with renewable energy sources) Tanulmány. (Study) Energia Klub. 17.

[43] Wikberg, J., Ogren, E. (2004): Inter-relationships between water use and growth traits in biomass-producing willows. - Trees 18: 70-76. 